Family Medicine and Community Health

\title{
Response to letter by Zhijie Xu: Why should mixed methods matter to primary care physicians and other providers?
}

\author{
John W Creswell, ${ }^{1}$ Mariko Hirose ${ }^{2}$
}

To cite: Creswell JW, Hirose M. Response to letter by Zhijie Xu: Why should mixed methods matter to primary care physicians and other providers? Fam Med Com Health 2019;7:e000217. doi:10.1136/ fmch-2019-000217

Received 01 August 2019 Accepted 01 August 2019

\section{Linked}

http://dx.doi.org/10.1136/ fmch-2019-000196

Check for updates

(C) Author(s) (or their employer(s)) 2019. Re-use permitted under CC BY-NC. No commercial re-use. See rights and permissions. Published by BMJ.

${ }^{1}$ BMJ Publishing Group, London, WC1H 9JR, UK

${ }^{2}$ Kwansei Gakuin University, Nishinomiya, Japan

Correspondence to Dr John W Creswell, University of Michigan, Ann Arbor, Ml 48109, UK;

creswell@med.umich.edu
Thanks for your positive, wonderful response to our article on 'Survey Research and Mixed Methods'. The question that you raise at the beginning is an important one for all countries around the world: 'Why should mixed methods matter to primary care physicians?'

To answer the question requires first defining what we mean by mixed methods research. You provide a good definition by mentioning how in this form of research, investigators use both quantitative and qualitative approaches to collect and analyse data, integrate the data and draw conclusions. I would add to this the three core ideas of mixed methods: integration, insight and designs. What distinguishes mixed methods from other approaches is the integration of the quantitative and qualitative data rather than gathering only one form of data or gathering both, but keeping the databases separate. Furthermore, it is through this integration that investigators gain additional insight not yielded by either the qualitative or quantitative data alone. Then, we have developed advanced procedures for how integration and insight occur through our mixed methods research designs. We feel that if you keep these three core ideas at the front of your thinking about mixed methods, you will have a good understanding of the methodology. See the text by Creswell and Plano Clark $^{1}$ and the Creswell book, A Concise Introduction to Mixed Methods Research ${ }^{2}$ that advance these ideas.

We do know indirectly that primary care is not widely recognised in China. Yes, we understand that resources are not available to carry out the research, there is limited access to funding, and published works are not needed for promotion. However, we wonder whether this is the case at major universities in China. Since we live part-time in Japan, we do know that primary care is growing in Japan as is also the recognition of the importance of mixed methods. The Japan Society for Mixed Methods Research hosts a mixed methods research conference each year attracting between 200 and 300 participants. Primary care research projects are being conducted by physicians in various parts of Japan. As China is a major international partner in research, we feel that primary care research and mixed methods will grow in China in future years.

But why should mixed methods matter to primary care physicians? It should matter because primary care physicians continually improve their skills, their relationships with patients and their understanding of their work. Mixed methods can provide a more complete understanding of primary care topics by assessing the general trends and relationships (quantitative data) as well as capturing the personal experiences and views of physicians and patients (qualitative data), and by gathering insight from integrating the databases.

Your comment raises several possibilities of topics valuable to primary care physicians, as well as suitable for mixed methods research: to improve work patterns, to learn about the effectiveness and feasibility of filling out hundreds of public health records for residents, to examine doctor's own careers, to learn about community-dwelling populations. Certainly, the topics helpful to primary care physicians will vary from country to country. A quick scan of the topics published in the Annals of Family Medicine, ${ }^{3}$ edited now from our Family Medicine Department at the University of Michigan, can illustrate the types of topics of interest to primary care medicine. You will see topics ranging from the essential role of primary care professionals, detecting and treating depression, 
dementia among African American and White veterans, patients who do not have insurance, opioid medication prescribing, suspected acute coronary syndrome and physician experiences of physical examinations. These are all topics helping primary care physicians with their practices, and the Annals has a long history of publishing mixed methods studies.

The mixed methods journal, the Journal of Mixed Methods Research, edited by the primary care physician, Dr Michael Fetters, at the University of Michigan also publishes mixed methods studies addressing topics in primary care. See, for example, the insightful article about patient and provider (general physician) relationships in the article by Schieber, Kelly-Irving, Genolini, et al. ${ }^{4}$ You can also see the list of primary care projects funded by the National Institute of Health in their searchable database called RePORT (National Institute of Health, NIH Research Portfolio Online Reporting Tools), https://report.nih. gov).

As you say, primary care researchers should have an interest in patient-reported outcomes and making an interpretation for them. Quality improvements in primary care cannot do without mixed methods. We agree.

Funding The authors have not declared a specific grant for this research from any funding agency in the public, commercial or not-for-profit sectors.

Competing interests None declared.

Patient consent for publication Not required.

Provenance and peer review Commissioned; internally peer reviewed.

Open access This is an open access article distributed in accordance with the Creative Commons Attribution Non Commercial (CC BY-NC 4.0) license, which permits others to distribute, remix, adapt, build upon this work non-commercially, and license their derivative works on different terms, provided the original work is properly cited, appropriate credit is given, any changes made indicated, and the use is non-commercial. See: http://creativecommons.org/licenses/by-nc/4.0/.

\section{REFERENCES}

1. Creswell JW, Plano Clark VL. Designing and conducting mixed methods research. 3rd. Sage Publishing, 2018.

2. Creswell JW. A Concise introduction to mixed methods research. Sage Publishing, 2015.

3. Annals of Family Medicine, July, August,2019, 17:4

4. Schieber A-C, Kelly-Irving M, Génolini J-P, et al. Integrating multidisciplinary results to produce new knowledge about the Physician-Patient relationship. J Mix Methods Res 2017;11:174-201. 